\title{
A Canção do Senhor na terra dividida: a música engajada dos protestantes brasileiros sob repressão militar e religiosa
}

\section{The Lord's Song in a Divided Land: the Engaged Music of Brazilian Protestants under Military and Religious Repression}

\author{
Joêzer de Souza Mendonça \\ Pontifícia Universidade Católica do Paraná, Curitiba, Paraná, Brasil. \\ joezer.7@gmail.com
}

Resumo: Este artigo examina uma seleção de cânticos protestantes socialmente engajados produzidos nos anos 1970, período em que a polarização culturalideológica entre "alienados" e "engajados" existente no circuito da música popular brasileira repercutiu na esfera da música cristã brasileira. 0 objetivo é averiguar os componentes de nacionalismo musical e engajamento social desses cânticos protestantes e também analisar como essas canções expressavam uma idealização do futuro, "o dia que virá" prognosticado tanto pelas canções de protesto seculares como também pelos cânticos protestantes.

Palavras-chave: canção brasileira de protesto; música protestante socialmente engajada; nacionalismo musical; música popular brasileira religiosa

Abstract: This paper examines a selection of socially engaged Protestant songs of the 1970s, when the cultural-ideological polarization between "alienated" and "engaged" in the sphere of Brazilian popular music reverberated in the realm of Brazilian Christian music. Our goal is to examine the components of musical nationalism and political and social engagement of those Protestant songs, and also to analyze how those songs expressed an idealization of the future, "the days to come" predicted both by secular protest songs and Protestant hymns.

Keywords: Brazilian protest song; socially engaged Protestant music; musical nationalism; religious popular Brazilian music

Data de recebimento: 03/02/2016

Data da aprovação final: 29/03/2016 
MENDONÇA, Joêzer de Souza (2016). A Canção do Senhor na terra dividida: a música engajada dos protestantes brasileiros sob repressão militar e religiosa. Per Musi. Ed. por Fausto Borém, Eduardo Rosse e Débora Borburema. Belo Horizonte: UFMG, n.34, p.113-131.

\title{
1 - Introdução
}

Ao afixar suas 95 teses na porta da igreja de Wittenberg em 1517, Martinho Lutero (1483-1546) protestava contra tradicionais interpretações teológicas do catolicismo romano. Seis anos depois, Lutero adicionaria o protesto musical à confrontação teológica. Em carta endereçada a Georg Spalatin, o reformador protestante manifestava seu intento de mobilizar a cultura musical popular germânica em reação à música litúrgica cantada em latim das missas católicas:

\begin{abstract}
"A fim de ser entendido pelo povo, somente as palavras mais simples e mais comuns deveriam ser usadas para o canto; ao mesmo tempo, elas devem ser genuínas e apropriadas. E, além disso, o sentido deve ser cristalino e o mais próximo possível do salmo" (LEHMAN, 1957-1986, p.68-69).
\end{abstract}

No entender de Lutero, toda a congregação deveria ser estimulada a compreender a mensagem bíblica. Essa conviç̧ão orientou a tradução da Bíblia e da liturgia da missa para o vernáculo, no caso, para a língua alemã, e também motivou a composição de cânticos no idioma natal. A formulação da Missa Luterana era uma nova proposta litúrgica, mas não deixava de enunciar também uma afirmação política.

Quase 500 anos depois, alguns dos herdeiros da Reforma Protestante que se espalhavam pelo Brasil estavam convictos da necessidade de mudanças políticas e espirituais de suas congregações. Em reação ao repertório estrangeiro que abundava em suas igrejas, e também em oposição ao autoritarismo do governo militar brasileiro recém-instalado, teólogos e músicos protestantes incorporaram o idioma musical popular brasileiro ao canto cristão, cuja letra foi acrescida de críticas à letargia religiosa e à passividade política da igreja no Brasil. Entre a cruz e o fuzil, sua atuação musical e seu pensamento ideológico enfrentaram a resistência dos irmãos de fé e dos compatriotas de farda.

Na segunda metade dos anos 1960, um debate cultural e ideológico também dividia os músicos brasileiros em dois grupos: de um lado, os fãs das jovens estrelas da Jovem Guarda, ala musical em que o trio de destaque formado por 
MENDONÇA, Joêzer de Souza (2016). A Canção do Senhor na terra dividida: a música engajada dos protestantes brasileiros sob repressão militar e religiosa. Per Musi. Ed. por Fausto Borém, Eduardo Rosse e Débora Borburema. Belo Horizonte: UFMG, n.34, p.113-131.

Roberto Carlos, Wanderléa e Erasmo Carlos cantava romances e aventuras inocentes. Não raro, seus sucessos eram adaptações de melodias do pop italiano e do rock norte-americano e inglês de sonoridade mais leve.

Do outro lado, estava o grupo que frequentava festivais de música popular, nos quais uma parcela das canções apresentadas criticava a repressão militar e incentivava a resistência política. Geraldo Vandré, Sérgio Ricardo e Chico Buarque destacavam-se como a voz dos estudantes politizados. Os músicos envolvidos como protesto ideológico empunhavam violões e pandeiros e adotavam o baião e o samba como estilos legítimos de afirmação cultural e política. Este segundo grupo protestava contra o regime autoritário imposto ao país após o golpe militar de 1964, repudiava a hegemonia da cultura norte-americana e valorizava a cultura popular nacional. Esse debate cultural-ideológico gerou a dicotomia entre "alienados", assim rotulados devido à ausência explícita de politização de suas canções, e "engajados", cujas músicas de implícito teor de protesto estavam ligadas aos eventos sociais e políticos correntes na época.

Uma polarização semelhante ocorreu na esfera da música protestante quando os setores cristãos mais politizados passaram a criticar não apenas a letargia espiritual como também a passividade política dos evangélicos brasileiros. Esse protesto dentro do protestantismo era tanto litúrgico/religioso quanto político/ideológico e combatia "o bom combate" em duas frentes: a política e a evangelização. No âmbito musical, esse combate político-evangelístico preconizava a rejeição aos hinos anglo-saxões, atrelados a uma cultura estrangeira, e a composição de canções religiosas baseadas nos estilos populares brasileiros, atrelados ao signo da autenticidade popular. Em resumo, a reação de teólogos e músicos protestantes contra o repertório de cânticos estrangeiros, tido como um indício do imperialismo econômico e cultural, propiciou a abertura para a incorporação de ritmos como a marcha-rancho, o baião, o samba e a bossa nova.

Ao analisar os componentes de nacionalismo musical e engajamento políticoreligioso nas canções protestantes compostas durante o período do governo militar, foi possível identificar que os aspectos musicais e ideológicos dessas 
MENDONÇA, Joêzer de Souza (2016). A Canção do Senhor na terra dividida: a música engajada dos protestantes brasileiros sob repressão militar e religiosa. Per Musi. Ed. por Fausto Borém, Eduardo Rosse e Débora Borburema. Belo Horizonte: UFMG, n.34, p.113-131.

canções nem encontraram fácil aceitação entre os evangélicos nem se tornaram conhecidos no âmbito da canção brasileira de protesto. Ao situar as canções protestantes no contexto musical, religioso e político do Brasil nos anos 1960/1970, também verifico se essas canções não estavam a emitir implicitamente uma idealização do futuro, "o dia que virá" nos libertar, prognosticado tanto pelas canções de protesto seculares como também pelos hinos protestantes sobre o fim do mundo.

\section{A fé cristã e a ideologia política}

Uma importante característica da canção cristã de protesto no Brasil era a enunciação de ações para a implantação de justiça social no mundo terreno agora mesmo, e não somente realizada por uma entidade celestial no futuro, num dia por vir. Esse aspecto resultava do fato de que os músicos cristãos que combinavam os estilos musicais populares com o discurso politicamente engajado tiveram contato com a Teologia da Libertação. ${ }^{1}$ Oriunda da reação de teólogos da Igreja Católica presentes na América Latina nos anos 1950-1960, a Teologia da Libertação era um movimento teológico-político que integrava os ensinamentos de Jesus Cristo em favor dos oprimidos e excluídos sociais. Seu raio de influência lhe deu caracteres de movimento inter-religioso de crítica e ação contra a injustiça social e a repressão política. No terreno protestante, o pensamento de teólogos como Rubem Alves e Richard Shaull deixou profundas marcas na mentalidade cristã das décadas de 1960 e 1970, ao passo que, no campo musical, notabilizou-se a influência do teólogo anglicano Jaci Maraschin.

As canções politizadas dos protestantes ecoavam as canções de protesto dos festivais dos anos 1960 (Festival da Música Popular Brasileira -TV Record, Festival Internacional da Canção - TV Globo) e a crítica social de Chico Buarque presente nas canções do LP Construção (Phonogram/Philips, 1971) e no compacto simples Apesar de Você (1970). Mas as canções dos protestantes engajados também

\footnotetext{
${ }^{1} 0$ termo "Teologia da Libertação" foi cunhado pelo padre peruano Gustavo Gutiérrez em seu livro Teologia de la Liberación, publicado em 1971. Leonardo Boff é outro expoente católico do movimento, assim como o teólogo belga José Comblin, autor de Teologia da Revolução (1970).
} 
MENDONÇA, Joêzer de Souza (2016). A Canção do Senhor na terra dividida: a música engajada dos protestantes brasileiros sob repressão militar e religiosa. Per Musi. Ed. por Fausto Borém, Eduardo Rosse e Débora Borburema. Belo Horizonte: UFMG, n.34, p.113-131.

estavam permeadas pela ação revolucionária e missiológica proposta pela Teologia da Libertação.

O protesto musical cristão também está enraizado em uma tradição religiosa e moral nascida na fé cristã. Há diversas passagens bíblicas em que o povo é convocado a cuidar de órfãos e viúvas, a libertar os oprimidos, a praticar a equidade, a alimentar o faminto e a denunciar a injustiça. As letras de denúncia social também comparecem no livro dos Salmos, embora os salmistas conclamem a ação divina, e não a atuação humana, para o livramento e a justiça. No livro de Amós, relata-se que a injustiça e o desprezo pelos mais necessitados entre os habitantes do Antigo Israel faziam com que os cânticos religiosos soassem como um "estrépito" aos ouvidos de Deus. ${ }^{2}$

O canto religioso como um ato político é uma característica da música dos escravos nos Estados Unidos do século XIX, em que os spirituals entoados nos cultos faziam referências camufladas ao desejo de liberdade, empregando histórias do cativeiro judeu em terras egípcias e babilônicas como metáfora de sua condição de povo oprimido. ${ }^{3}$ Esse repertório está na base do surgimento das canções de ativismo político da população afro-americana, como We shall over come. A canção cristã como ato político foi ouvida também no movimento antiapartheid na África do Sul: Syahamba! We are marching in the light of God. Quando os manifestantes marchavam contra a opressão, sua música também enfatizava que eles estavam sob a luz de Deus. Desse modo, o canto religioso assumia implicações políticas que estariam no cerne de certas proposições bíblicas de fraternidade e justiça. ${ }^{4}$

\section{A música cristã de protesto}

Da composição de letras e músicas que resultavam da politização dos estudantes, e também a partir do envolvimento de teólogos e músicos protestantes com a

${ }^{2}$ Cf. Salmos 9:4, 72:2 e 103:6; Provérbios 31:8, 9; Isaías 58: 6,7; Amós 5:12, 23,24; Tiago 1:27 (A Bíblia Sagrada. Nova Versão Internacional).

${ }^{3}$ Cf. canções como "Go down, Moses, way Egypt's Land", "Steal away to Jesus", "This train is bound for glory".

${ }^{4}$ Cf. o capítulo "Singing as political act: Theological soundings of justice", em SALIERS (2007). 
MENDONÇA, Joêzer de Souza (2016). A Canção do Senhor na terra dividida: a música engajada dos protestantes brasileiros sob repressão militar e religiosa. Per Musi. Ed. por Fausto Borém, Eduardo Rosse e Débora Borburema. Belo Horizonte: UFMG, n.34, p.113-131.

Teologia da Libertação, surgiu o movimento denominado MPBR (Música Popular Brasileira Religiosa) representado pelos nomes de Jaci Maraschin, Laan Mendes de Barros, Simei Monteiro, Sérgio Marques Lopes, Valdomiro Pires de Oliveira e vários outros. Suas novas canções fomentaram oportunidade para discussões sobre o amadurecimento político dos evangélicos e sobre o papel da música na liturgia dos cultos.

Os debates realizados pela Associação de Seminários Teológicos Evangélicos (ASTE) na década de 1970 abordavam a temática da utilização dos gêneros musicais nacionais na liturgia e legaram uma conscientização quanto ao posicionamento da igreja em relação às questões nacionais mais urgentes. Criaram, também, condições para o surgimento de hinários como A canção do Senhor na Terra Brasileira e O Novo Canto da Terra. Para DOLGUIE (2007, p.215), esses hinários reuniam canções que reagiam contra a "alienação social das letras dos cânticos importados".

Uma canção bastante representativa desse pensamento intitula-se Que estou fazendo?, de João Dias de Araújo e Décio E. Lauretti. Trata-se de uma reflexão da experiência cristã pessoal que busca estimular as ações de justiça social:

Milhões não sabem como escrever, milhões de pobres não sabem ler Nas trevas vivem sem perceber que são escravos de um outro ser Que estou fazendo se sou cristão, se Cristo deu-me o seu perdão? Há muitos pobres sem lar, sem pão, há muitas vidas sem salvação Aos poderosos eu vou pregar, aos homens ricos vou proclamar Que a injustiça é contra Deus e a vil miséria insulta os céus ${ }^{5}$

O relato de Décio Lauretti confirma a identificação do movimento protestante com o movimento engajado de valorização da cultura brasileira pela via da Teologia da Libertação:

[...] eu havia lido 'Jesus Cristo, Libertador', do Leonardo Boff, que me impressionou bastante. [...] os textos de Rubem Alves, os textos de John Robinson, Tillich, Bonhoefer e tantos outros sedimentaram em mim uma visão menos conservadora do que a

\footnotetext{
${ }^{5}$ Esses versos estão assim registrados no Hinário para o Culto Cristão, no 552. A gravação do grupo Água Viva (LP MILAD 2,1989) traz algumas alterações na letra original e o ritmo utilizado não foi o baião, e sim um frevo em andamento lento.
} 
MENDONÇA, Joêzer de Souza (2016). A Canção do Senhor na terra dividida: a música engajada dos protestantes brasileiros sob repressão militar e religiosa. Per Musi. Ed. por Fausto Borém, Eduardo Rosse e Débora Borburema. Belo Horizonte: UFMG, n.34, p.113-131.

então vigente na Igreja Presbiteriana do Brasil [O poema de João Dias de Araújo] pregava um cristianismo engajado na luta contra as injustiças, distante da religião enclausurada nos templos, que busca a 'salvação da alma' e ignora o corpo, especialmente os corpos dos desfavorecidos. Decidi musicá-lo, optando por uma sequência harmônica barroca num ritmo brasileiro, o baião. ${ }^{6}$

Na avaliação de FATARELLI (2008, p.58), “ao tratar da imensa população de pobres, ao enfocar uma salvação que leva o indivíduo a ser parte do projeto divino que combate toda forma de opressão e injustiça", a letra de Que Estou Fazendo? enseja os principais temas da Teologia da Libertação. Nessa perspectiva, a canção cristã de protesto identifica-se com a parcela mais pobre da população e com as lutas em prol da liberdade. Esse novo modelo de composição emprega estilos e instrumentos originários das classes populares (samba, frevo, baião, sertanejo, marcha-rancho). Desse modo, “o popular se torna sagrado, sem ter que esvaziar-se de sua origem, de sua identidade popular" (BARROS, 1988, p.213).

Essa identidade popular foi incorporada por meio da adoção litúrgica da música de extração popular brasileira, a "música do povo". Por meio de versos como "Falo na nova língua do povo / palavras que já tem gosto, Senhor / palavras do coração" e "Quero mudar a face do mundo / e dar-lhe amor mais profundo, Senhor", e também por meio do uso do ritmo no baião e seu padrão melódico mixolídio, o cântico Canto o novo canto da terra, de Simei Monteiro, efetuava essa dupla função do novo canto litúrgico em terra brasileira. ${ }^{7}$

No aspecto musical, as composições protestantes nacionais contrastavam com a simplicidade harmônica de cânticos estrangeiros, como os corinhos, cuja estrutura musical provinha de estilos norte-americanos como o country e o rockabilly. Não raro, isso favorecia uma progressão harmônica que percorria, preferencialmente, os graus I, IV e V (tônica, subdominante e dominante) da tonalidade, em geral, dando-se primazia a tonalidades maiores (Dó Maior, Lá Maior, Sol Maior). Conhecidos cânticos do meio evangélico na década de 1970, como Aleluia, Satisfação e Seguindo a Jesus (trecho abaixo), exibem essas características:

\footnotetext{
${ }^{6}$ A íntegra do relato de Décio Lauretti está disponível em <www.luteranos.com.br/textos/queestou-fazendo-se-sou-cristao>.

7 Tal como consta no Hinário para o Culto Cristão, no 549.
} 
MENDONÇA, Joêzer de Souza (2016). A Canção do Senhor na terra dividida: a música engajada dos protestantes brasileiros sob repressão militar e religiosa. Per Musi. Ed. por Fausto Borém, Eduardo Rosse e Débora Borburema. Belo Horizonte: UFMG, n.34, p.113-131.

Dó (C)

Estou seguindo a Jesus Cristo

Fá (F) Dó

Desse caminho, eu não desisto

Dó

Estou seguindo a Jesus Cristo

Sol (G) Dó

Atrás não volto nunca mais

Por outro lado, a estrutura melódica e harmônica dos cânticos protestantes socialmente engajados possuía características ligadas à musicalidade popular nacional. Há maior desenvoltura harmônica, como o uso de tonalidades menores (Ré menor, Mi menor, Lá menor) e do ciclo das quintas. Em geral, a linha melódica é mais sinuosa, com ocorrência de acidentes (notas que não pertencem à escala tonal da canção), e há uso de síncopes comuns em estilos como a marcha-rancho, a bossa nova e o baião.

O cântico Que estou fazendo? está escrito na tonalidade de Ré menor (Dm) e faz a progressão harmônica do círculo das quintas: ${ }^{8}$

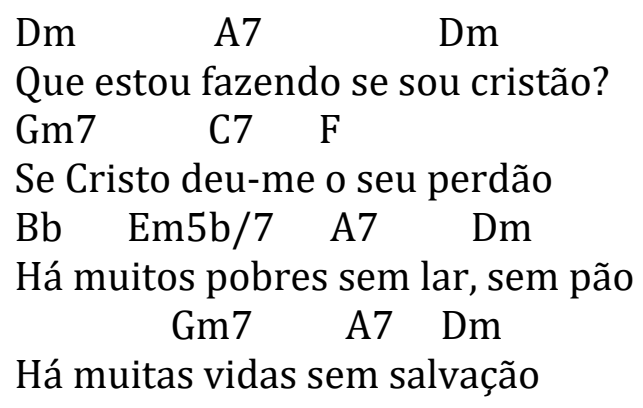

No início da década de 1960, o mote dos Centros Populares de Cultura (CPC) ${ }^{9}$ indicava a preeminência do político sobre outras dimensões da vida social: "Fora da arte política não há arte popular" (MARTINS, citado por HOLLANDA, 1980,

8 Tonalidade do cântico registrado no Hinário para o Culto Cristão, no 552.

9 O Centro Popular de Cultura, criado em 1961, era uma agremiação ligada à União Nacional dos Estudantes (UNE). Foi organizado por intelectuais e estudantes universitários com objetivo de suscitar a conscientização política e social por meio da criação de uma arte popular revolucionária. Sua extinção se deu após o golpe militar em 1964. 
MENDONÇA, Joêzer de Souza (2016). A Canção do Senhor na terra dividida: a música engajada dos protestantes brasileiros sob repressão militar e religiosa. Per Musi. Ed. por Fausto Borém, Eduardo Rosse e Débora Borburema. Belo Horizonte: UFMG, n.34, p.113-131.

p.131). Renato ORTIZ (1998, p.75) avalia que, na interpretação do CPC, somente a arte política poderia ser considerada como legítima, uma vez que ela encarna a única forma possível de réplica ao processo de alienação. Para um dos principais ideólogos do CPC, Carlos Estevam Martins (citado por GARCIA, 2004, p.150), “a cultura que o CPC propõe-se a levar ao povo é aquela que seus membros chamam de cultura para a libertação. Trata-se da utilização da vanguarda cultural para a conscientização do povo, o que lhe facultará, posteriormente, a tomada do poder".

Nesse cenário cultural e ideológico, alguns músicos protestantes, em número pequeno diante da maioria conservadora, modularam para o terreno da religião a discussão sobre arte política e arte popular. Foram compostas, então, várias canções que combinavam os temas da fraternidade cristã e do ativismo social e político, cuja forma musical era uma afirmação cultural nacionalista e cujo conteúdo era uma advertência ao estado de alienação religiosa e política dos seus irmãos de fé.

Em O Novo Canto da Terra, publicado em 1987, há letras que conjugam amor ao próximo e luta revolucionária:

Quero mudar a face do mundo E dar-lhe amor mais profundo, Senhor, do que se costuma dar. Pois Cristo veio e morreu, e veio para ficar, E vem comigo lutar, lutar, E vem comigo lutar, vem lutar, vem lutar (MARASCHIN, 1987, p. 397)

Vem, instaura o novo mundo onde o amor seja a linguagem, e que seja o amor profundo: seja o norte dessa viagem. Queima tudo o que enfeitiça: o poder do braço iníquo; rompe o cerco da injustiça que separa o pobre do rico (MARASCHIN, 1987, p. 238)

Outras letras nos ajudam a compreender melhor a influência do nacionalismo musical e da Teologia da Libertação na canção cristã de protesto:

Benção da Mesa (Jaci Maraschin): 
MENDONÇA, Joêzer de Souza (2016). A Canção do Senhor na terra dividida: a música engajada dos protestantes brasileiros sob repressão militar e religiosa. Per Musi. Ed. por Fausto Borém, Eduardo Rosse e Débora Borburema. Belo Horizonte: UFMG, n.34, p.113-131.

Senhor, Te damos graças porque em volta desta mesa

Renova-nos a força de lutar contra a pobreza

[...] Senhor, que os nossos pratos, numa terra dividida

Um dia se dividam numa terra reunida

Saudade da pátria - Salmo 137 (Valdomiro Pires de Oliveira):

E o nosso louvor não é nossa canção:

Não é um samba, uma modinha, um chorinho nem baião

Elevamos ao Senhor o cântico impingido pelos opressores:

No seu ritmo, na sua instrumentação

[...] Se não preferirmos a canção brotada

Desse chão menino, brasileiro, latino,

Que a nossa língua apegue-se ao paladar

E que não possamos mais cantar

Embora essas músicas estivessem identificadas com o debate nacional-popular que circundava a MPB, BARROS (1988, p. 200) considera que a proposta de uma canção cristã referenciada em estilos e instrumentos musicais nacionais não era um simplismo ufanista ou um "exercício de patriotismo purista", mas uma "valorização das expressões culturais originais de grupos populares".

Em sua canção, Valdomiro de Oliveira liga a memória do povo hebreu no exílio babilônico (Salmo 137) ao contexto nacional do povo brasileiro nos anos 19601970. Os versos conectam-se também com o sentimento de dependência latinoamericana em relação às potências econômicas mundiais e identificam-se com a valorização da musicalidade brasileira. No dizer de MARASCHIN (1996, p.136), "precisamos mostrar a sacralidade maravilhosa do violão, dos tambores, dos pandeiros. Experimentar a beleza do nosso samba, da nossa marcha-rancho, do nosso xaxado".

A contextualização da canção cristã de protesto no cenário da Teologia da Libertação e dos debates ideológicos e estéticos das décadas de 1960 e 1970 permite, portanto, a visão de um modelo de canção religiosa que se identificava com o lugar sociogeográfico das classes populares, que sacralizava os ritmos nacionais e que ensejava a "conscientização política", no caso, das congregações evangélicas. 


\section{O dia por vir dos protestantes e o "dia que virá" dos engajados}

Alguns analistas da música cristã feita sob a ditadura militar consideram que certos grupos musicais evangélicos dos anos 1970, como Vencedores por Cristo, foram "instrumentos de alienação", visto que a temática de suas letras enfatizava "uma abordagem escatológica que apontava somente para o porvir, um enfoque da fé cristã totalmente desvinculado da realidade social, tratando o tema de maneira romântica, idealista" (BARROS, 1988, p.126). Além disso, as letras seriam permeadas de clichês que "promoviam a acomodação e passividade" das propagandas oficiais do governo e reforçavam "princípios teológicos/ideológicos fundamentalistas", o que leva à conclusão de que o conteúdo apocalíptico/escatológico ${ }^{10}$ das canções gravadas pelos grupos evangélicos era um discurso integrado ao sistema de repressão política do regime militar (BARROS, 1988, p.200).

Para Magali CUNHA (2007, p.80), as igrejas locais não acolhiam as canções protestantes engajadas devido a sua preferência em preservar "o núcleo da mensagem tradicional do protestantismo brasileiro", identificado com uma postura antiecumênica, sectária e individualista, e em manter um posicionamento concordante com os ideais ufanistas e apaziguadores divulgados pelo governo militar. Nesse sentido, a canção cristã de protesto foi desqualificada pela ala conservadora da igreja por ser uma canção política e não uma canção "autenticamente" cristã, enquanto a canção cristã tradicional foi desqualificada pelos engajados por não ser nem brasileira e nem política (e, sob o signo da ação humanitária, nem mesmo cristã).

${ }^{10}$ Escatologia é a área da teologia que estuda as doutrinas concernentes aos últimos eventos do mundo (ou fim do mundo). 
MENDONÇA, Joêzer de Souza (2016). A Canção do Senhor na terra dividida: a música engajada dos protestantes brasileiros sob repressão militar e religiosa. Per Musi. Ed. por Fausto Borém, Eduardo Rosse e Débora Borburema. Belo Horizonte: UFMG, n.34, p.113-131.

Na avaliação de NAPOLITANO (2002, p.66), um mito historiográfico colado à MPB engajada se refere ao argumento de que "a MPB era mistificadora", pois oferecia aos setores intelectuais "apenas uma catarse escapista (marcada pelo culto do 'dia que virá' nos libertar)". A crítica ao suposto caráter escapista de certas canções de protesto se devia ao fato de que suas letras pareciam prorrogar a libertação para uma data possível apenas no futuro, para o "dia que virá". Seguem alguns exemplos (grifos meus):

Ponteio (Edu Lobo e Capinam):

Encerrar meu cantar já convém / Prometendo um novo ponteio

Certo dia que sei por inteiro / Eu espero não vá demorar

Esse dia estou certo que vem / Diga logo que vim pra buscar Correndo no meio do mundo / Não deixo a viola de lado Vou ver o tempo mudado / E um novo lugar pra cantar

Apesar de você (Chico Buarque):

Apesar de você, amanhã há de ser outro dia

Sabiá (Tom Jobim e Chico Buarque):

Sei que ainda vou voltar / E é pra ficar

Sei que o amor existe / Eu não sou mais triste

E que a nova vida já vai chegar/ E que a solidão vai se acabar

Em um texto polêmico, Walnice GALVÃO (1976, p.104) avaliava que esse adiamento paralisava o movimento de mudança política e social: "Negando-se a fazer e esperando para ver a chegada de um novo dia, 'a canção da MMPB [Moderna Música Popular Brasileira] resulta, portanto, numa evasão à implicação pessoal de cada um na história'”. 
MENDONÇA, Joêzer de Souza (2016). A Canção do Senhor na terra dividida: a música engajada dos protestantes brasileiros sob repressão militar e religiosa. Per Musi. Ed. por Fausto Borém, Eduardo Rosse e Débora Borburema. Belo Horizonte: UFMG, n.34, p.113-131.

Nessa perspectiva, as canções divulgadas nas reuniões promovidas pelas organizações paraeclesiásticas ${ }^{11}$ também estariam prorrogando o dia da libertação para o porvir: "Aqui no mundo as desilusões são tantas / Mas existe uma esperança / é que Ele vai voltar" (trecho da canção Momentos). Além disso, seu conteúdo pietista e apaziguador implicaria uma fuga da dura realidade social: "Meu sonho, a paz achei enfim / Jesus em mim" (da canção Nada Melhor).

A canção cristã tradicional foi criticada por suas letras referentes ao segundo advento de Cristo e ao Juízo Final como soluções únicas para os males do mundo. A canção evangélica não politizada e os hinos protestantes "importados" configurariam também uma "catarse escapista", pois embora ressaltem os temas da fraternidade, a mudança integral da sociedade só poderia ser efetivada por uma entidade divina.

Por sua vez, os compositores da nova canção cristã, cientes de que "quem sabe faz a hora, não espera acontecer", não postergavam a libertação para um futuro porvir, e sim, requeriam-na no presente, promovendo um enfoque religioso consciente da realidade social. Diz o trecho da letra de Esperança, canção de Jaci Maraschin:

Aprisionado numa só cadeia

0 povo quer e busca libertação

Que os desolados, os pobres e os sem lar

possam cantar, vibrantes,

a vitória de um reino que começa aqui e agora (MARASCHIN, 1987, p. 77)

Contudo, as canções presentes em $O$ Novo Canto da Terra ressaltam alguns temas que também são enfatizados na canção de protesto popular: o termo "esperança" comparece em 30 composições; "libertação", "libertar" e "libertador" constam em 27 composições; "pão" e "reino" estão em 21 canções; "terra” em 20; "justiça” em 16 e "evangelho" em 10 canções (FATARELLI, 2007, p.60). Do seu modo, a canção religiosa de protesto também enunciava "o dia que virá", o "Juízo Final" como o dia da libertação completa:

11 Organizações paraeclesiásticas, oriundas dos Estados Unidos, que se estabeleceram no meio evangélico nos anos 1950-1960: Palavra da Vida, Os Jovens da Verdade, Mocidade para Cristo, SEPAL (Serviço de Evangelização para a América Latina). 
MENDONÇA, Joêzer de Souza (2016). A Canção do Senhor na terra dividida: a música engajada dos protestantes brasileiros sob repressão militar e religiosa. Per Musi. Ed. por Fausto Borém, Eduardo Rosse e Débora Borburema. Belo Horizonte: UFMG, n.34, p.113-131.

Salmo 2 (Jaci Maraschin / Simei Monteiro):

Por que há nações orgulhosas / Querendo um domínio total?

Negando a Deus e em nome da paz / Destroem em vez de livrar.

Por que se acumulam riquezas / Por que há pobreza e opressão?

Cuidado, nações, aprendam lições: / Juízo de Deus vai chegar! (MARASCHIN, 1987, p.468)

Convite à liberdade (Sérgio Matos):

E vós os oprimidos, e vós os explorados / E vós os que viveis em agonia E vós os cegos, coxos, vós cativos, sós, / Sabei que em breve vem um novo dia. Um dia de justiça, um dia de verdade / Um dia em que haverá na terra paz Em que será vencida a morte pela vida / E a escravidão enfim acabará

Apesar do engajamento político, tais canções também estariam promovendo uma idealização do futuro, "o dia que virá" prognosticado pelas canções de protesto seculares e, também, pelos rejeitados hinos da escatologia protestante. Por outro lado, ao se estudar a canção evangélica tradicional dos anos 1970, não se pode deixar de ver a orientação da mentalidade da maioria dos protestantes, como o sentido de missão evangelizadora por meio da metodologia do "Discipulado Cristão",12 assim como também se nota a reprodução das músicas do grupo Vencedores por Cristo nos meios de comunicação de massa em detrimento das músicas da "Nova Canção" socialmente engajada (SILVA, 2001, p.25).

Por fim, a visão de que a esperança de justiça divina e "o dia que virá" são pretextos escapistas da realidade não observa que

"É certo que nem a MPB, (...) ou qualquer outro movimento na música brasileira, estavam em condições de ameaçar a ordem político-social. Não obstante, ao fazer a crítica e defender a mudança, a MPB contribuiu para a politização do seu público, incitando a uma reflexão que já indicava uma resistência às arbitrariedades" (VILARINO, 2001, p.114).

12 Discipulado Cristão é um modelo de estudo, comunhão e prática baseado em princípios bíblicos e adotado por algumas igrejas evangélicas. 


\section{Resistência evangélica ao canto cristão de protesto}

Nas igrejas evangélicas, a introdução das canções protestantes socialmente engajadas se deu de maneira mais "lenta e gradual" do que a abertura política do regime militar proposta pelo presidente Ernesto Geisel. Os autores da "Nova Canção" protestante nem sempre encontravam acolhida entre os músicos cuja formação musical clássica/erudita impedia a inserção de um repertório baseado na música de raiz nacional.

A reação da ala conservadora da igreja protestante no Brasil não endossou a canção cristã de protesto social. Se considerarmos as sérias imbricações entre o aparelho repressor da ditadura militar e alguns aliados ultraconservadores dentro da igreja evangélica, o que gerou um clima de temor e delacionismo entre os próprios evangélicos, ${ }^{13}$ podemos ter uma dimensão da resistência a essa canção que criticava tanto a repressão política militar quanto a alienação social e a falta de ação humanitária por parte dos religiosos.

Os grupos tradicionais das igrejas protestantes, que já se opunham às guitarras e baterias trazidas pela nova geração de músicos, também não aceitaram a presença de instrumentos utilizados em ritmos populares brasileiros. Em um contexto mais amplo, podemos ponderar algumas razões da resistência à música popular brasileira religiosa:

1- O segmento jovem, mais afeito a inovações, preferia rocks e baladas norteamericanas em vez da música brasileira de origem secular ou cristã. Certas organizações paraeclesiásticas estavam alinhadas a uma interpretação mais tradicional da mensagem bíblica e incentivavam um alto padrão de conduta moral, visto por alguns como sectarismo e negação do mundo. Outros analistas, porém, observam seu alinhamento ao modelo de ufanismo promovido pelo governo

\footnotetext{
${ }^{13}$ Esse controverso aspecto da relação entre a ditadura e as igrejas evangélicas pode ser lido no artigo sobre o conteúdo dos documentos do Projeto Brasil: Nunca Mais repatriados em 2008 pelo Conselho Mundial das Igrejas disponível em<http://www.creio.com.br/2008/noticias01.asp?noticia=14126>.
} 
MENDONÇA, Joêzer de Souza (2016). A Canção do Senhor na terra dividida: a música engajada dos protestantes brasileiros sob repressão militar e religiosa. Per Musi. Ed. por Fausto Borém, Eduardo Rosse e Débora Borburema. Belo Horizonte: UFMG, n.34, p.113-131.

militar (ALMEIDA, s/d, p.6). As canções desses grupos eram, muitas vezes, "versões em português de cânticos populares estaduninenses (marchas e baladas românticas)”, em geral, “de fácil melodia, versos curtos e ritmo animado" (CUNHA, 2007, p.70).

Por seu turno, DOLGHIE (2007, p.217) conclui que a música de caráter nacional teve pouca aceitação entre a juventude evangélica por que a música americana impregnara o gosto dos jovens brasileiros. Parecia consolidada "uma mentalidade conservadora que projetava sua admiração no modelo estrangeiro" (BARROS, 1988, p. 94).

2- As lideranças mais tradicionais rejeitavam os estilos nacionais como uma "pedra de escândalo". O samba e o baião remetiam a fortes conotações de "mundanismo" e não eram adequados aos propósitos litúrgicos. Defendendo a posição de que manifestações culturais populares não são adequadas ao contexto litúrgico, João Faustini (citado por BARROS, 1988, p.94) afirmava que "a música sacra ideal é a que se pode descrever como reverente, digna e inteiramente isenta de qualquer laivo de expressão secular".14

Quando o grupo musical Vencedores por Cristo gravou o LP De Vento em Popa (1977), álbum com maior combinação de ritmos nacionais e internacionais e menor referência religiosa nas letras, a vendagem foi pequena e a rejeição, grande (FILHO, 2005, p.62).

3- As letras daquelas canções apresentavam um alto teor de denúncia social e politização, o que assustava as mentes politicamente mais conservadoras e, também, poderia associar a igreja aos movimentos de guerrilha que radicalizavam a resistência política. Nesse contexto, "foi se acentuando o conflito entre posições reacionárias pietistas e posições progressistas, entre uma teologia fundamentalista e uma teologia da libertação" (BARROS, 1988, p.94)

14 BARROS (1988) referencia a fala de João Faustini no texto de James Frederick Spann, "A influência da música popular na música sacra contemporânea", in Música e Igreja, Simpósio n. 16, p.13. 
MENDONÇA, Joêzer de Souza (2016). A Canção do Senhor na terra dividida: a música engajada dos protestantes brasileiros sob repressão militar e religiosa. Per Musi. Ed. por Fausto Borém, Eduardo Rosse e Débora Borburema. Belo Horizonte: UFMG, n.34, p.113-131.

4- Nascida no meio católico, a Teologia da Libertação combinava Bíblia e marxismo e visava à libertação política e espiritual das camadas populares marginalizadas. Enquanto o Vaticano bania padres ligados ao movimento, os setores protestantes não apoiavam a aproximação do grupo de compositores da MPBR com a Teologia da Libertação, o que trouxe prejuízos à disseminação do novo estilo musical.

Nessa breve análise das razões da resistência evangélica às canções de protesto cristãs, nota-se que a música popular brasileira religiosa era nacional demais para uma parcela da juventude, mundana demais para os tradicionalistas, comunista demais para os conservadores e católica demais para os evangélicos.

\section{Considerações Finais}

O envolvimento de teólogos e músicos protestantes com a Teologia da Libertação e com o ativismo político universitário nas décadas de 1960 e 1970 trouxe para a igreja o debate sobre identidade cultural nacional e sobre a participação política dos evangélicos numa sociedade empobrecida e ainda sob um governo militar autoritário. As canções que derivaram do polo religioso politicamente engajado serviam para fortalecer as ações de mudança social encampadas pelos cristãos e também para conscientizar politicamente os chamados grupos alienados. 0 convite era tanto para a luta revolucionária quanto uma advertência à letargia espiritual dos evangélicos.

Por vezes, estas canções reproduziam em suas letras aquilo que pretendiam criticar: o ufanismo militar do "Brasil Grande" era reprovado pelos protestantes engajados, embora o elogio da brasilidade e da cultura popular observado nas canções cristãs de protesto chegasse às raias do ufanismo e da superioridade cultural sociogeográfica; a escatologia apocalíptica protestante também era vista como "alienação" da participação política no presente, mas às vezes as canções religiosas engajadas reproduziam o "dia que virá" presente nas canções seculares de protesto e nos hinos "importados". 
MENDONÇA, Joêzer de Souza (2016). A Canção do Senhor na terra dividida: a música engajada dos protestantes brasileiros sob repressão militar e religiosa. Per Musi. Ed. por Fausto Borém, Eduardo Rosse e Débora Borburema. Belo Horizonte: UFMG, n.34, p.113-131.

Em meio ao clima de insatisfação política, musical e litúrgica, algumas congregações protestantes registraram uma animosidade pouco fraterna e nada cristã. E mesmo no novo século, apesar da formação de uma sólida indústria fonográfica gospel, os gêneros musicais considerados nacionais ainda encontram oposição nas igrejas de origem protestante histórica/tradicional. Contudo, em que pese o conservadorismo político ainda latente, abriu-se no protestantismo, desde então, maior espaço ao rebuscamento poético das letras, à diversidade estilística musical e à conscientização do papel do cristão na sociedade.

\section{Referências}

1. ALMEIDA, Francisco Thiago de. (s/d). A música protestante brasileira em tempos de repressão política. Disponível em http://pt.scribd.com/doc/54226648/11-A-Musica-Protest-Ante-BrasileiraFranciscoALMEIDA. Acesso em 04 out. 2014.

2. BARROS, Laan Mendes. (1988). A canção de fé no início dos anos 70: harmonias e dissonâncias. Dissertação de Mestrado em Comunicação Social, Universidade Metodista de São Paulo.

3. CUNHA, Magali do Nascimento. (2007). A explosão gospel: um olhar das ciências humanas sobre o cenário evangélico no Brasil. Rio de Janeiro: Mauad X, Instituto Mysterium.

4. DOLGHIE, Jacqueline Ziroldo. (2007). Por uma sociologia da produção e reprodução musical do presbiterianismo brasileiro: a tendência gospel e sua influência no culto. Tese de doutorado em Ciências da Religião, Universidade Metodista de São Paulo.

5. FATARELI, Uéslei. (2008). A influência da teologia da libertação em composições musicais protestantes brasileiras. Cad. CERU, São Paulo, v. 19, n. 2. Disponível em <http://www.revistasusp.sibi.usp.br/scielo.php?script=sci_arttext\&pid=S1413$45192008000200008 \& \operatorname{lng}=$ pt\&nrm=iso $>$. Acesso em 10 jan. 2012.

6. . (2007). Cantai ao senhor um cântico novo: influência da teologia da libertação no canto protestante brasileiro. Dissertação de Mestrado em Ciências da Religião, Universidade Presbiteriana Mackenzie.

7. FILHO, Jorge Geraldo de Camargo. (2005). De vento em popa: fé cristã e música popular brasileira. São Paulo, Universidade Presbiteriana Mackenzie.

8. GALVÃo, Walnice Nogueira. (1976). Saco de gatos. Ensaios críticos. São Paulo, Duas Cidades. 
MENDONÇA, Joêzer de Souza (2016). A Canção do Senhor na terra dividida: a música engajada dos protestantes brasileiros sob repressão militar e religiosa. Per Musi. Ed. por Fausto Borém, Eduardo Rosse e Débora Borburema. Belo Horizonte: UFMG, n.34, p.113-131.

9. GARCIA, Miliandre. (2004). A questão da cultura popular: as políticas culturais do Centro Popular de Cultura (CPC) da União Nacional dos Estudantes (UNE). In: Revista Brasileira de História. São Paulo, v. 24, no 47, p. 62-127.

10. GONÇALVES JR, Valter. (2011). “A vida nos anos de chumbo”. Cristianismo Hoje, junho. Disponível em http://www.cristianismohoje.com.br/interna.php?id_conteudo=579. Acessoem21 out. 2014.

11. LEHMANN, Helmut T. (1957-1986). Luther's works, vols. 31-55. Philadelphia: Fortress Press.

12. MARASCHIN, Jaci. (1996). A beleza da santidade: ensaios de liturgia. São Paulo: Aste.

13. (1987). O novo canto da terra. Instituto Anglicano de Estudos Teológicos.

14. MARTINS, C. E. (1980). Anteprojeto do Manifesto do Centro Popular de Cultura redigido em março de 1962. In: HOLLANDA, H. B. de. Impressões de viagem: CPC, vanguarda e desbunde: 1960/1970. São Paulo: Brasiliense, p.121-44.

15. NAPOLITANO, Marcos. (2002). História e Música: história cultural da música popular. Belo Horizonte: Autêntica.

16. ORTIZ, Renato. Cultura brasileira e identidade nacional. (1998).São Paulo: Brasiliense.

17. SALIERS, Don E. (2007). Music and Theology (Horizons in Theology). Nashville, TN (USA): Abingdon Press.

18. SILVA, Fábio Henrique Pereira. (2001). O Novo Canto da Terra: estudos sobre sua contribuição à renovação litúrgico-musical das igrejas evangélicas. São Bernardo do Campo: Universidade Metodista de São Paulo.

19. VILARINO, Ramon Casas. (2001). A MPB em movimento: música, festivais e censura. São Paulo: Olho d'Água.

Notas sobre o autor

Joêzer de Souza Mendonça é professor do Curso de Licenciatura em Música da Pontifícia Universidade Católica do Paraná (PUCPR). Tem mestrado e doutorado em Musicologia pela Universidade Estadual Paulista (UNESP), com tese que pesquisa a Teomusicologia, campo de estudos que analisa as relações entre religião, música sacra e canção popular. É autor do livro "Música e Religião na Era do Pop" (Curitiba: Appris, 2014). 